Revue d'études américaines. American Studies Journal

$2 \mid 2017$

(Hi)stories of American Women: Writings and Rewritings / Call and Answer: Dialoguing the American West in France

\title{
Lytle Shaw, Narrowcast: Poetry and Audio Research
}

\section{Aurore Clavier}

\section{OpenEdition}

\section{Journals}

Electronic version

URL: https://journals.openedition.org/transatlantica/10585

DOI: 10.4000/transatlantica.10585

ISSN: 1765-2766

Publisher

Association française d'Etudes Américaines (AFEA)

Electronic reference

Aurore Clavier, "Lytle Shaw, Narrowcast: Poetry and Audio Research", Transatlantica [Online], 2 | 2017, Online since 23 May 2019, connection on 02 February 2023. URL: http://journals.openedition.org/ transatlantica/10585 ; DOI: https://doi.org/10.4000/transatlantica.10585

This text was automatically generated on 2 February 2023.

\section{c) (1) $(9)$}

Creative Commons - Attribution-NonCommercial-NoDerivatives 4.0 International - CC BY-NC-ND 4.0 https://creativecommons.org/licenses/by-nc-nd/4.0/ 


\title{
Lytle Shaw, Narrowcast: Poetry and Audio Research
}

\author{
Aurore Clavier
}

\section{REFERENCES}

Lytle Shaw, Narrowcast: Poetry and Audio Research, Stanford, Stanford University Press, 2018, 254 pages, $27 €$, ISBN-10: 1503606562

1 Underlying Lytle Shaw's study Narrowcast: Poetry and Audio Research is a fertile operation of critical recording. If, shaw explains, narrowcasting has come to designate "niche marketing and "special interests" (3) he proposes to go beyond the "normative evaluations" (3) this mercantile view entails and to widen the conceptual scope of the term, all the while engaging in his own meticulous version of "close listening" (Bernstein, 1998). His analysis focuses on the recorded works of several American poets associated with the New Left-mainly Allen Ginsberg, Larry Eigner, Charles Olson and Amiri Baraka-, from the mid-1960s to the late 1970s, a time-frame he situates between the emergence of tape-recording as a relatively novel process among writers and its more widespread and therefore unremarkable use in the following decades.

2 As Lytle Shaw's engaging introduction establishes, Narrowcast participates in the larger development of sound, performance and media studies observed in recent decades, reflecting the critics' increasing interest in poetry readings and recordings, as evidenced by the author's discussion of Michael Davidson's Ghostlier Demarcations: Modern Poetry and the Material Word (1997), Charles Bernstein's Close Listening: Poetry and the Performed Word (1998), or Raphael Allison's more recent Bodies on the Line: Performance and the Sixties Poetry Reading (2014), to name a few. However, the originality of Shaw's perspective lies in the more surprising poetic and political implications his analysis uncovers. Although he does address the more traditional questions raised by recording technologies, he is less concerned with matters of textual authority or with 
the writers' (un)mediated presence as with the ways in which the poets' audio-works may challenge the dominant media of postwar Northern America.

3 To this end, the study is structured around "four connected senses of narrowcasting" (3): implicitly drawing on Shaw's previous study, Fieldworks: From Place to Site in Postwar Poetics (2013), the first sense is a spatial one and registers the poets' turn to the "countermedia space[s]" of their immediate environments, away from the disembodied and falsely universal "non-site" of mainstream broadcasting (3). Closely tied to the former, the second, temporal, sense embraces the alternative temporalities explored by the poets, against the more strictly "administered versions of national time" (1) imposed by the media, from the division of days by radio programs to the promotion of "The American Century" by Henry Luce's media empire (94). Adapting a useful distinction from art history, Shaw proposes to interpret the poets' play on fragmented time or their cultivation of ongoingness as various instances of genre recording as opposed to the monumental temporality of history (sometimes complicating some of these New Left poets' commitment to contemporary politics). Eluding even the artists' control over their own production, the third form of narrowcasting refers to the artifactual quality Shaw perceives in the "opaque, noisy sonic surface" (4) of recordings, in which a variety of contingent sounds (from surrounding noises to bodily manifestations) compete with the more intentional delivery of the poems. The methodological sense of narrowcasting the book finally articulates offers a welcome challenge to received assumptions about audio recording, and about research at large. In the wake of the New Left poets, who refused to submit to dominant models of interpretation, Shaw chooses to circumvent ready-made literary lineages and theoretical frameworks, in favor of a more inductive process of deciphering. Exploiting the relative independence of his field from "long critical histories, agreed-upon evidentiary status and sedimented levels of methodology," Shaw uses four main case studies as a "testing ground for method" (18): in-depth descriptions serve a "horizontal model of theorization in which literary and historical texts are often reverseengineered as articulations of conceptual models no less authoritative than those offered by the theoretical or philosophical discourses they frequently merely illustrate" (9).

4 Despite the rigor of Shaw's investigation, readers might regret the limited attention he devotes to the scholar's own listening conditions. Although he does evoke the everincreasing access to academic resources and the multiplicity of potential narratives researchers now have to consider, a more reflexive questioning of the institutional ties and artifactual qualities of audio archives would have enriched Shaw's analysis of the "metacommentary" intrinsically generated by recording, which, in Fredric Jameson's words, reflects both "history itself" and "the historical situation of the commentator" (Jameson, 1988, 10; quoted in Shaw, 2018, 13). On the other hand, Shaw's methodology proves most convincing when it carefully adjusts to unsuspected or heretofore neglected audio practices. Among his most challenging discoveries are certainly the ties he establishes between countercultural audio research and the governmental surveillance secretly, if not illegally, conducted by the CIA and the FBI. Far from treating state-led activities as a mere contextual element foregrounding the New Left poets' resistance to Cold-War ideology, Shaw fully integrates their analysis to his case studies and methodological questioning, often uncovering surprising convergences between seemingly antagonistic approaches. Institutional ghost-listening therefore 
becomes an essential, though paradoxical, component of the audio research he intends to explore.

5 In chapter 1, entitled "Third Personism: The FBI's Poetics of Immediacy in the 1960s," the author proposes to reframe Frank O'Hara's notion of "Personism" by involving a third-unacknowledged-participant in the intimate telephone conversations evoked in the poet's 1959 essay. The reel-to-reel recordings Allen Ginsberg made during the cross-country trip that would inspire the first part of The Fall of America: Poems of these States, 1965-1971 (1972) is thus placed in dialogue with the audio surveillance he had become the object of by the mid-1960s. Quite expectedly, Shaw contrasts the state's anti-communist agenda and Ginsberg's countermedia project: while the "mobile bard" (36) simultaneously aimed to register the radio's consumerist messages or political propaganda, and his own poetic response to their deleterious effects in America and beyond, his pro-Cuban and anti-Vietnam War positions gradually drew state agents' attention, as had Amiri Baraka's own political leanings. "Tape," however, "may coil in conflicting ethical directions" (37), engaging more unlikely crossings between countercultural recordings and the "poetics" of surveillance Shaw examines. Despite evidently diverging goals, both the poet and his ghost-listeners were confronted with the artefactual resistance of their medium, a resistance they did not fully integrate to their research, written transcription ultimately prevailing over recorded documents. Shaw also underlines the similarities between interpretive paradigms in which the collection of evidence was determined by a preexisting set of hypotheses, be it Ginsberg's criticism of media-generated alienation, or James Angleton's and Edgar Hoover's communism-oriented theories. In so doing, the author qualifies the belief in a "ham-fisted misunderstanding of experimental poetry" by "communism obsessed ColdWarriors" (28) just as he revises the myth of the spontaneous, unmediated nature of Ginsberg's work.

6 The close readings composing chapter 2, "The Eigner Sanction: Keeping Time from the American Century," provide a most subtle example of the "search for alternate temporalities" (1) underlying New American poetry and Narrowcast alike. If Larry Eigner's work is replaced within a wide network of correspondence and recordings, Shaw is careful to avoid the critical reclamations attempted by successive groups of authors, from the Beat to the Black Mountain and more recently to the Language poets. While poets and critics may have valued Eigner's experimental verse as a retreat from the surrounding world and a reflexive questioning of language, both resulting from his cerebral palsy and the limited control he had over his environment, Shaw examines the ways in which radio airwaves or aircraft activity became part of an ambient surround he tried to register within his fragmented lines. Comparing his writing mode "to an alternative, real-time radio station keyed to the daily sonic and visual developments in his neighborhood" (29), the chapter analyzes the "shifting membranes and ambiences of his poems," (77) as defining features of genre poetry, foregrounding conditions over events, ongoingness over historical ruptures. Eigner's poetry does not only circumvent the prescriptive organization of media time, but also distinguishes itself from more poetic forms of engagement with history, from Allen Ginsberg's critique of media politics, to Charles Olson's “collage historicism” (88). The peculiarity of Eigner's counter-temporality and of his domestic "field poetics" (85) is put into further relief by the analysis of various tape and film recordings, in which the cultivation of a "nonmonumental now" (88) surfaces through the complex negotiations these 
documents entailed between the scripted poem and other performers' voices, or between shifting sonic textures and porous visual environments.

Dedicated to "Olson's Sonic Walls: Citizenship and Surveillance from the OWI to the Nixon Tapes," Chapter 3 seeks to inflect received assumptions about both Olson's ambiguous links with the American empire and his gradual shift from state politics to poetry, by retracing the author's engagement with audio and linguistic research from his early work at the Office of War Information to various recordings of the Maximus Poems. An early pamphlet written while he was assistant chief of the Foreign Language Division initiates a sonic trajectory gradually leading from an inclusive nation to his Gloucester surroundings-"less the empirical town than a town-sized peerdom of interlocutors" (109)-, and ultimately to the poet's body itself, even while the scope of his epic seemed to expand to cosmological dimensions. The complex interplay between Olson's assumed audience and his institutional position at the heart of postwar American poetry is evinced by the recorded readings Shaw analyzes and by the illuminating parallels he draws with experimental sound and performance works by Robert Morris and Vito Acconci. This evolution is placed within the larger framework of the country's war and postwar interests: Olson's contribution to the OWI becomes a symptom of the "weaponization" of sound, music and language by wartime anthropology (111), which laid the groundwork for the strategic development of area studies and language laboratories during the Cold War. The ideological and practical ramifications of these new academic practices come into focus through a complementary case study: following Henry Kissinger's career from his Harvard education and later editorial activities to his key involvement in the Johnson and Nixon administrations, the chapter demonstrates how the secretary of state's linguistic training may have prefigured the rise of audiotape espionage and the emergence of an “"avant-garde' form of surveillance" in which-as opposed to "the more classic evidentiary models" described in chapter 1-“documentation precedes (or transcends) a driving hypothesis" (31). If the chapter's developments sometimes render its internal coherence less visible, the final link it establishes between Kissinger's model of research and Olson's open-ended fieldwork-against more rigid critical constructions of the latter's historical epic-convinces the reader of the efficacy of Shaw's method.

8 The fourth and final chapter, entitled "The Strategic Idea of North: Glenn Gould, Sergeant Jones, and White Alice," further highlights the wide geopolitical underpinnings of narrowcasting. Shaw sets off to explore the development of sound studies through the pioneering audio work of R. Murray Schafer and Glenn Gould on Canadian soundscapes. As Shaw demonstrates, the natural noises, radio signals, local accents their on-site recordings attempted to weave together contributed to redefine the Canadian listener's interactions with his surroundings, questioning the centrality of human presence all the while cultivating the "sound citizen" 's attention to his sonic environment. But the map Shaw uncovers reveals a more problematic relationship to national territory, reticulated as it was by the successive lines of American radar stations designed to monitor Soviet intrusion across the Canadian Arctic and inform the Colorado-based White Alice complex of a potential military threat. The virtual mechanics of escalation implied by this transcontinental system is envisaged through the individual course of Sergeant LeRoi Jones who, before his years of political and poetical activism as Amiri Baraka, practiced mock reprisal raids for the U.S. Air Force in anticipation of an attack. The "screaming hellish sirens" (169) that set the cadence of his time in the army appear as a necessary, though negative, step in the sonic 
formulation of Black Nationalism in the poet and critic's later work. Although his writings and recordings seem inscribed within a revolutionary time, the sonic effects contained in the 1972 LP It's Nation Time, or in John Coltrane's jazz rendition of the Broadway classic "My Favorite Things," suggest a commitment to the ongoingness of genre and to the active recoding of the "compromised sound" of mainstream culture, as temporal alternatives to historical rupture.

Despite the thoroughness of Shaw's introduction and of each successive chapter, a conclusion may have enhanced the overall coherence of his various case-studies and better highlighted the fruitfulness of the author's inductive method. However, navigating from close readings to cultural panoramas suffices to reveal the originality and quality of this contribution to literature, sound and performance studies, and more broadly to intellectual and political histories. Behind the coterie logic of the New American poets, the book discloses the deep spatial and temporal implications of the audio experiments they conducted, wavering between site-specific, if not deeply embodied, practices and vast geopolitical underpinnings, confronting the fractures of a troubled history with the non-monumental and open-ended temporality of ongoingness. The alternative narrative Shaw thus proposes- while always questioning the validity of narrative itself-helpfully proves that antagonistic goals did not always entail diverging practices, when it focuses on the research modes and misunderstandings shared by countercultural poets and secret agents. The blind spots and failures of audio research pinpointed by Narrowcast-from the poets' neglect of the potentialities contained within their faulty medium to the relative invisibility of experimental tape recording after the 1970s-probably constitute one of the study's most stimulating dimensions, calling for a continuation of Shaw's fascinating fieldwork into the following decades.

\section{BIBLIOGRAPHY}

Works Cited

ALLISON, Raphael, Bodies on the Line: Performance and the Sixties Poetry Reading, Iowa City, University of Iowa Press, 2014.

BARAKA, Amiri, It's Nation Time, LP, Newark (NJ), Jihad, 1972.

BERNSTEIN, Charles, ed., Close Listening: Poetry and the Performed Word, New York, Oxford University Press, 1998.

DAVIDSON, Michael, Ghostlier Demarcations: Modern Poetry and the Material Word, Berkeley, University of California Press, 1997.

GINSBERG, Allen, The Fall of America: Poems of These States, 1965-1971, San Francisco, City Lights, 1972.

JAMESON, Fredric, "Metacommentary," The Ideologies of Theory, Essays, 1971-1986, vol. 1, Situations of Theory, Minneapolis, University of Minnesota Press, 1988. 
OLSON, Charles, The Maximus Poems, ed. George Butterick, Berkeley, University of California Press, 1983.

INDEX

Subjects: Recensions

\section{AUTHORS}

AURORE CLAVIER

Université de Lille 